\title{
Evaluating the Digital Transformation of Cities with Multi-Criteria Decision-Making Techniques*
}

\section{Çok Kriterli Karar Verme Teknikleri ile Kentlerin Dijital Dönüşümünün Değerlendirilmesi}

\author{
Mustafa Çoruh $^{1}$ (D), Halil İbrahim Cebeci ${ }^{2}$ (D)
}

"This study was produced from the doctoral thesis titled "Determination of Critical Success Factors for the Digital Transformation of Cities and Ranking 81 Provinces According to the Urban Digitization Indices."

${ }^{1}$ Ataşehir Adıgüzel Vocational School, Ataşehir, Istanbul, Turkey

${ }^{2}$ Asst. Prof., Sakarya University, Faculty of Business Administration, Department of Management Information Systems, Sakarya, Turkey

ORCID: M.Ç. 0000-0002-7114-0372; H.İ.C. 0000-0001-5058-7741

\section{Corresponding author:}

Mustafa ÇORUH,

Ataşehir Adıüzzel Vocational School, Ataşehir, Istanbul, Turkey

E-mail address: mcoruh@mustafacoruh.com

Submitted: 05.06 .2021

Revision Requested: 15.06 .2021

Last Revision Received: 21.06.202

Accepted: 22.06 .2021

Published Online: 13.09.2021

Citation: Coruh, M., \& Cebeci, H. I. (2021)

Evaluating the digital transformation of cities with multi-criteria decision-making techniques. Acta

Infologica. Advance online publication.

https://doi.org/10.26650/acin.948458

\begin{abstract}
The integration of mobile and digital technologies with sensors enables cities to become Digital and Smart City (SC), and thus to provide city services more productively and effectively. Therefore, measuring the weighted and unweighted Digital Transformation (DT) Level of cities has been determined as one of the important problems of cities. For this purpose, the indicators, dimensions and Critical Success Factors (CSF) affecting the DT of cities were determined through literature review, questionnaires and interviews. The effects of indicators, dimensions and CSFs on the weighted Urban Digitalization Index (UDI) calculation were investigated. The Questionnaire answered by the municipality Information System (IS) experts was used to calculate the indicators, dimension and CSF weights. In these measurements, the SWARA technique was used in the calculation of CSFs weight percentages, the AHP technique was used in the calculation of dimensions weight percentages, and the Categorical Value Selection technique was used in the calculation of indicators weight percentages. The TOPSIS technique was used to transform three weighted UDI ranks into an integrated ranking. Satyam technique was used in the calculation of different UDIs. Use of the Satyam technique in UDI calculation for the first time in the world and the use of different Multi-Criteria DecisionMaking techniques together with the TOPSIS method in weighted UDI ranking increases the importance of the research. As a result, it is stated that weighted and unweighted UDI rankings can be used by city administrators in developing SC policies and strategies.
\end{abstract}

Keywords: Digital Transformation, Urban Digitalization Index, TOPSIS Technique

Öz

Yeni mobil ve dijital teknolojiler sensörlerle bütünleşerek kentlerin Dijital Dönüşümünü (DD) ve Akıllı Kent (AK) haline gelmesini ve bu sayede kent hizmetlerinin daha verimli ve etkin bir şekilde yerine getirilmesini sağlamaya başlamışlardır. Bu yüzden kentlerin ağılıklı ve ağırlıksız DD Seviyesinin ölçülmesi kentlerin önemli sorunlarından birisi olarak belirlenmiştir. Bu amaçla literatür taraması, anketler ve mülakatlar vasıtasıyla kentlerin Dijital Dönüşümünü etkileyen göstergeler, boyutlar ve Kritik Başarı Faktörleri (KBF) belirlenmiş ve bunların ağırlıklı ve ağırlıksız Kent Dijitalleşme Endeks (KDE) değerlerinin hesaplanmasına etkileri araştırılmıştır. Ağırlıklı KDE’lerin hesaplanmasında kullanılan Gösterge, Boyut ve KBF ağıllıklarının hesaplanması için belediye Bilgi İşlem (Bİ) uzmanları tarafından cevaplanan Anketler kullanılmıştır. KBF ağırlık yüzdelerinin hesaplanmasında SWARA, boyut ağırlık yüzdelerinin hesaplanmasında AHP ve gösterge ağırlık yüzdelerinin hesaplanmasında Kategorik Değer Seçme tekniği kullanılmıştır. Bu yüzde ağırlık değerleri yardımıyla oluşturulan üç adet ağırlıklı KDE sıralaması da TOPSIS tekniği kullanılarak bütünleşik ağırlıklı bir sıralamaya dönüştürülmüştür. KDE'lerin hesaplanmasında ise Satyam tekniği kullanılmıştır. KDE hesaplamasında Satyam tekniğinin Dünya'da ilk defa kullanılması ve farklı Çok Kriterli Karar Verme tekniklerinin ağırlıklı KDE sıralamasında TOPSIS yöntemiyle birlikte kullanılması araştırmanın önemini artırmaktadır. Sonuçta ağırlıklı ve ağırlıksız KDE sıralamalarının kent yöneticileri tarafından AK politikaları ve stratejileri geliştirmede kullanabilecekleri belirtilmiştir.

Anahtar kelimeler: Dijital Dönüşüm, Kent Dijitalleşme Endeksi, TOPSIS Tekniği 


\section{INTRODUCTION}

Digital Transformation (DT) changes the rules of doing business, management, and living in every field from beginning to end. The governments of the cities are also affected by this. The spread of new Information (Digital) and Mobile Technologies are transforming cities' management models and service processes. Therefore, like countries, NGOs, companies, and universities, cities have to find ways of DT by adapting to the Digital Age. It should not be forgotten that the Digital Transformation of a city means becoming a Smart City (SC) (Satyam, 2017).

Research Problem: It is obvious that today cities have to deal with many problems. In this study, it is advocated that solutions can be produced through DT for the ineffective and unproductive use of urban resources, which is one of the main problems of cities. For this, it is suggested that the Digital Transformation Level of cities must be measured. In other words, Urban Digitalization Indexes (UDI) must be determined. In order to determine the UDI of the cities, the dimensions, Critical Success Factors (CSF), and indicators that ensure the DT of cities must be determined, and their effects on weighted and unweighted UDIs must be found. Multi-Criteria Decision Making (MCDM) techniques are used to find dimension, CSF, and indicator weights and calculate UDIs with the help of these in the ranking of cities. For this purpose, transforming the weighted dimension, CSF, and indicator ranking used in calculating UDIs into an integrated ranking with the TOPSIS method has been determined as the problem of this research.

Aim of the Study: In line with the identified problem, first of all, it was tried to determine the indicator, dimension, and CSF weights that determine the UDI of the cities. For this, indicators, dimensions, and CSFs affecting the Digital Transformation of cities were determined through literature review, interviews, and surveys. These were put into a table, and MCDM techniques were used to find their weights with the help of surveys. The SWARA technique was used to find CSF weights, the AHP technique was used to find dimension weights, and the Categorical Value Selection technique was used to find indicator weights. The UDI rankings formed with these three different weighted values have been transformed into an integrated ranking with the TOPSIS technique. For this reason, the purpose of the research was determined as "to achieve an integrated UDI ranking by integrating different MCDM methods".

However, since the aim of the research is to use a suitable method to fulfill the research purpose rather than to compare the methods used or to determine their superiority to each other, only the methods that were decided upon to be used in the research were attempted to be introduced in the literature review, findings, and method sections. Thus, the TOPSIS method, which is used to obtain an integrated ranking from different weighted UDI rankings, was introduced. Therefore, only the basic features of other methods that could be used are mentioned in the relevant sections.

Research Questions: In this research, answers to the following questions were sought to achieve the aim stated above:

1. What are the Dimensions, CSFs, and Indicators that affect cities' Digital Transformation (Digitalization)?

2. With which MCDM techniques and how can Dimension, CSF, and Indicator percent weight values be measured?

3. How can UDI rankings based on different weight values be transformed into an integrated ranking for city administrators?

The Importance of the Study: Finding the indicators, CSFs, and dimensions that determine the Digital Transformation level of cities and trying to help city managers make new decisions for the Digital Transformation of cities by determining different UDI rankings with the help of these, reveal the importance of this research. In addition, transforming the UDI rankings created with different MCDM techniques into an integrated ranking with the TOPSIS method increases the importance of the research. This integrated ranking can help city administrators to determine SC policies and strategies.

Target Audience of the Study: City and Municipality administrators, municipal IS officials, and other city stakeholders.

\section{LITERATURE REVIEW}

Numerous organizations and research groups worldwide make city classifications such as the most livable city, the best global city, the smartest city, the most digital city, and the best city to find jobs. Lately, in the world and Turkey, various indices 
relating to the Digital Transformation of the economy, businesses, and Smart Cities are being developed by different international and national institutions. Because numerical indicators related to DT of these entities have become extremely important for designing national and international policies (TÜBİSAD, 2020, s. 19), m any indicators, dimensions, and CSFs affect the Smart or Digital Cities have been revealed in these studies. Cities often use these SC Index rankings to increase their publicity and improve their position in competition between cities (SCRanking, 2007).

In line with the literature review and the interviews made in Zonguldak districts, the dimensions, CSFs, and indicators of the Digital Transformation of Cities are given in Table-1. Details of how these are determined can be found in the research (Çoruh M. , 2021) conducted in Zonguldak districts and 81 provincial centers in Turkey. In this study, 88 indicators were used to measure CSF and dimension values. The list of indicators is given in Annex-1.

Table 1

Dimensions, CSFs and Indicators Affecting the Digital Transformation of Cities

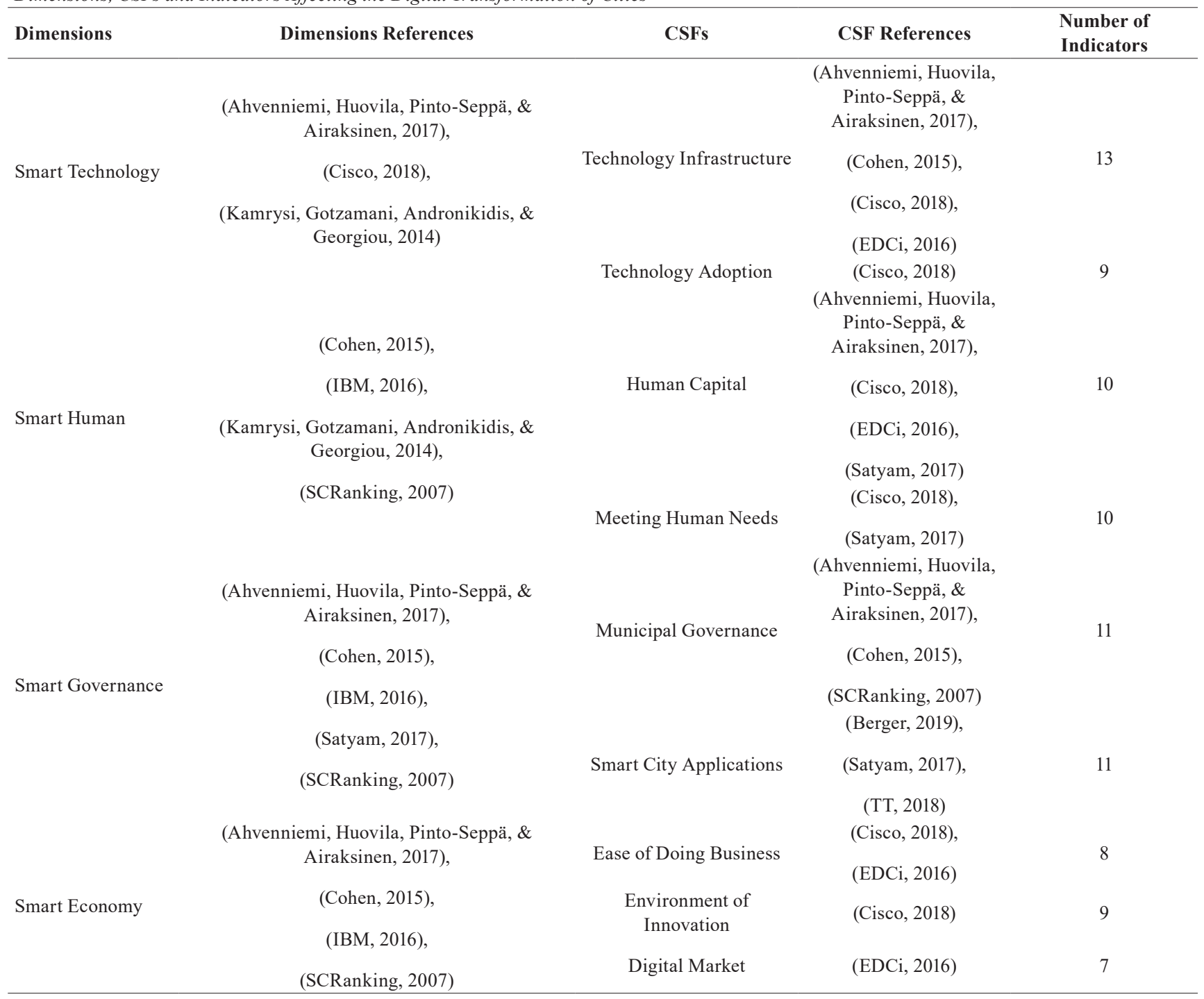

Source: (Çoruh, 2021)

In scholarly researches, indicators, dimensions, and CSFs used in the calculation of UDIs are generally used with the help of weights determined in line with expert opinions by using Multi-Criteria Decision Making (MCDM) techniques such as Categorical Value Selection, SWARA, ENTROPY, DEMATEL, Analytical Network Process (ANP) and Analytical Hierarchy Process (AHP). Objective weighting techniques such as ENTROPY are primarily used when there is appropriate data for determining the weight percentages of these elements. However, other techniques such as SWARA, ANP, and AHP techniques 
are generally used in line with expert opinions in cases with no data available. Özkaya and Erdin's (2020) research on the evaluation of smart and sustainable cities with ANP and TOPSIS can be given as an example.

SWARA (Step-wise Weight Assessment Ratio Analysis) technique, one of the MCDM techniques used in this study, is a multi-criteria weight calculation method developed by V. Kersuliene et al. (2010). In the method, the criteria used in the evaluation of alternatives are listed from important to unimportant and unimportant criteria are firstly eliminated by voting . Then, while calculating the weights of the remaining criteria, the total geometric mean of the rankings created by each expert is taken. In this technique, each expert ranks the importance of each criterion from the most unimportant to critical and determines the significance ratio among them (Ayçin, 2019, s. 222).

The main advantage of this method in MCDM techniques is that there is no need for any evaluation to define priorities and ranking criteria in some problems. However, in decision problems with many criteria, it becomes challenging to use AHP or ANP with too many paired comparisons. In the SWARA method, the weighting percentage can be obtained by making fewer comparisons. In this method, N-1 comparisons are made for N criteria (Ayçin, 2019, s. 222).

The SWARA technique, details of which can be accessed from the relevant resource, consists of the following stages (Ayçin, 2019, s. 222):

1. Stage: Determination of criteria and decision-makers.

2. Stage: Determining the importance order of the criteria.

3. Stage: Determining the relative importance of the criteria. Here, it is determined by what percentage ( $\%)$ the $\mathrm{j}$ criterion is more important than the $(\mathrm{j}+1)$ criterion. This determined value is indicated as $\mathrm{Sj}$.

4. Stage: The following formulas are used in determining the Kj Coefficient.

$$
\begin{aligned}
& \text { If } \mathrm{J}=1 \text { then } \mathrm{Kj}=1 \\
& \text { If } \mathrm{J}>1 \text { then } \mathrm{Kj}=\mathrm{Sj}+1
\end{aligned}
$$

5. Step: The following formulas are used in determining the Qj Coefficient.

$$
\begin{aligned}
& \text { If } J=1 \text { then } Q j=1 \\
& \text { If } J>1 \text { then } Q j=Q(j-1) / S j
\end{aligned}
$$

6. Stage: In determining the relative weights of the criteria, the following Formula is used.

$$
\mathrm{Wj}=\frac{Q j}{\sum_{k=1}^{n} Q k}
$$

On the other hand, Analytical Hierarchy Process (AHP) is an MCDM technique performed by giving relative values to decision alternatives and criteria in complex decision problems. Many decision problems contain both objective and subjective elements. AHP offers a more flexible and convenient solution due to its structure that addresses both of these elements (Timor, 2011, s. 26). T. Saaty developed AHP in the 1980s: With this MCDM method, objective and subjective decision criteria can be compared, and a ranking can be obtained as a result of weighting based on different decision criteria. AHP stands out as an MCDM technique that can be used in complex decision problems and especially in problems with subjective decision elements (Timor, 2011, s. 26).

After determining the target in AHP, a selection is made among alternatives with the help of criteria. Therefore, AHP works on the following three elements (Baltalar, 2008):

1. Simple Mathematics: Uses basic mathematics in AHP calculations. These are four operations, namely addition, subtraction, multiplication, and division.

2. Criterion: Anything that seems essential to the decision-maker (price, quality, distance, factor, etc.).

3. Standard Preference Table: It contains values used to indicate how important each criterion is to the decision-maker. 
Usually, values between 1 and 9 are used. For example, one suggests that the two factors are of e qual value, a value of 3 indicates Slightly More Important (Less Superior), a value of 5 indicates Quite Important (High Superiority), a value of 7 indicates Very Important (Very Superior), a value of 9 indicates Extremely Important (Absolute Superiority), and a value of 2, 4, 6, 8 are Intermediate Values (Consensus Values). In short, values between 2 and 9 indicate how many times one criterion is worth to another.

Technical details of AHP calculations can be found in Ayçin (2019), Timor (2011), and Baltalar (2008)

Indicators are the basic parameters that affect the smartness or digitalization of cities and contribute to the competitiveness of cities in the Urban Digitization Index ranking. However, the contribution of each indicator in this competition may be different. The difference in the indicator percentage (\%) weights requires its effect to be predominant in CSFs and their dimensions. Due to many indicators, it is necessary to find an applicable method to measure their weights. One of these measurement techniques is the "Categorical Value Selection" technique. This technique can be obtained by choosing a categorical value between 0 and 5 or 7 . Then, the following formula is used in calculating the five-selection of an indicator weight values (Aihemaiti A. , 2018, s. 29):

$$
W=0 * P 0+1 * P 1+2 * P 2+3 * P 3+4 * P 4
$$

In this Formula, the ratio of $\mathrm{P} 0$ corresponds to the election percent (\%) of 0 in the questionnaire and $\mathrm{P} 1$ to the election percent $(\%)$ of 1 , etc. Thus, the weight of $\mathrm{P} 0, \mathrm{P} 1, \mathrm{P} 2, \mathrm{P} 3$, and $\mathrm{P} 4$ in the equation is the proportion of $0,1,2,3$, and 4 in the questionnaire answers given to the indicator to be calculated, that means P0 + P1 + P2 + P3 + P4 =100\%. Here, the following Formula is used to calculate Pi percentages:

$\mathrm{Pi}=\mathrm{Xi} * 1 / \mathrm{N}$

$\mathrm{Xi}$ : Indicator answer number, $\mathrm{N}$ : Total number of answers.

It is helpful to recalculate the calculated weight values with the normalization formula to normalize the distortion of maximum and minimum values. Different formulas are used according to maximization or minimization problems in MCDM techniques. For example, in the case of maximization problems, the following normalization formula can be used (Aihemaiti A. , 2018, s. 29):

$$
\text { Normalized } W i=\frac{(W i-\operatorname{Min}(w))}{(\operatorname{Max}(w)-\operatorname{Min}(w))}
$$

Wi: Original value of the indicator, $\operatorname{Max}(w)$ : Maximum value, Min $(w)$ : Minimum value.

Methods such as Z-Score, Euclid Distance, and Satyam technique determine the Urban Digitalization Indexes. In this study, the Satyam UDI technique was used in the calculation of UDIs, but no other research was found in the literature review for the Satyam technique. In the Satyam UDI calculation technique, the details of which are not given in this research, Urban Digitization Maps (UDM) are created with the Digitization (CSF) Ratio results calculated from the indicator values. Then, the UDI is calculated by dividing the sum of the triangular areas on these maps by the largest circle area containing these triangles. In the calculation of UDIs, (Aihemaiti A., 2018) can be consulted for Z-Score, (EDCi, 2016) for Euclidean Distance, and (Satyam, 2017), (Çoruh M., 2021) and (Çoruh \& Cebeci, 2020) for Satyam technique.

There are different alternative methods such as DEA, VIKOR, EDAS, WASPAS, and TOPSIS to bring different rankings into a single ranking. For example, VIKOR provides a compromise solution between decision alternatives in optimizing complex systems with many criteria (Ayçin, 2019, p. 368). With the WASPAS method, more reliable rankings can be made with the integrated use of Weighted Sum and Weighted Product models (Ayçin, 2019, p. 308). The EDAS method is a method in which rankings are made by calculating the distances to the mean solution (Ayçin, 2019, p. 100). The TOPSIS method, on the other hand, is based on the optimization of positive and negative ideal solution results. Each of these methods can be used to determine the rankings in this research. However, the TOPSIS method was used because it does not involve too complex calculations to bring three different rankings made according to Weighted UDI values into an integrated ranking. 
The TOPSIS method developed by Hwang and Yoon in 1980 is one of the MCDM methods. Decision-makers frequently prefer TOPSIS in many different fields because they are easy to understand and do not contain complex mathematical calculations. The method proposes that the most appropriate decision alternative is close to the positive ideal solution and far from the negative ideal solution. Therefore, it bases its calculations on the distances from these points. It enables the decision alternatives to be ranked by comparing the distances (Ayçin, 2019, s. 292). In the TOPSIS method, solutions are calculated with a 6-step process (Ayçin, 2019, s. 293):

1. Stage: Creation of the decision matrix (A).

2. Stage: Creation of the standard decision matrix (R).

3. Stage: Creation of the weighted standard decision matrix (V).

4. Stage: Determination of positive ideal (A *) and negative ideal (A-) solution values.

5. Stage: Calculation of the distance from positive and negative ideal points (n: shows the number of variables).

Distance between two points: $=d_{i j}=\sqrt{\sum_{k=1}^{n} \quad\left(X_{i k}-X_{j k}\right)^{2}}$

Positive ideal distance: $=S_{i}^{*}=\sqrt{\sum_{j=1}^{n}\left(V_{i j}-V_{j}^{*}\right)^{2}}$

Negative ideal distance: $=S_{i}^{-}=\sqrt{\sum_{j=1}^{n}\left(V_{i j}-V_{j}^{-}\right)^{2}}$

6. Stage: Calculation of relative proximity to the ideal solution.

Relative proximity to the positive ideal solution: $=C_{i}^{*-}=\frac{s_{i}^{-}}{s_{i}^{-}+s_{i}^{*}}$

Because of these features, TOPSIS is used to integrate different rankings in research . Details of the TOPSIS method can be found in (Ayçin, 2019) and other internet sources.

\section{METHODS}

In this research, determining the weights of indicators, dimensions, and CSFs that contribute to determining the weighted and unweighted Digital Transformation Levels of the cities, namely the UDIs was attempted. In this calculation process shown in Figure-1, indicators express the raw data at the lowest level. Digitalization Ratios $(\mathrm{a} / \mathrm{b})$ were obtained from these raw data. Other Relevant Ratios were found by multiplying these ratios with CFS, Dimension, and Indicator percentages (\%) calculated by SWARA, AHP, and Categorical Value Selection techniques. With the help of these ratios, Urban Digitalization Maps (UDM) were created. After these UDM were calculated from triangle areas, the ratio of the circle area in the radar chart is divided with the measured UDM area. This is called the "Satyam UDI" calculation technique. These UDI values are used in the overall ranking of cities. In addition, cities could be listed from different angles with different weighted UDIs calculated with the help of different ratio values. The weighted UDI rankings calculated with the help of these different weights were transformed into an integrated weighted ranking order with the TOPSIS method. 


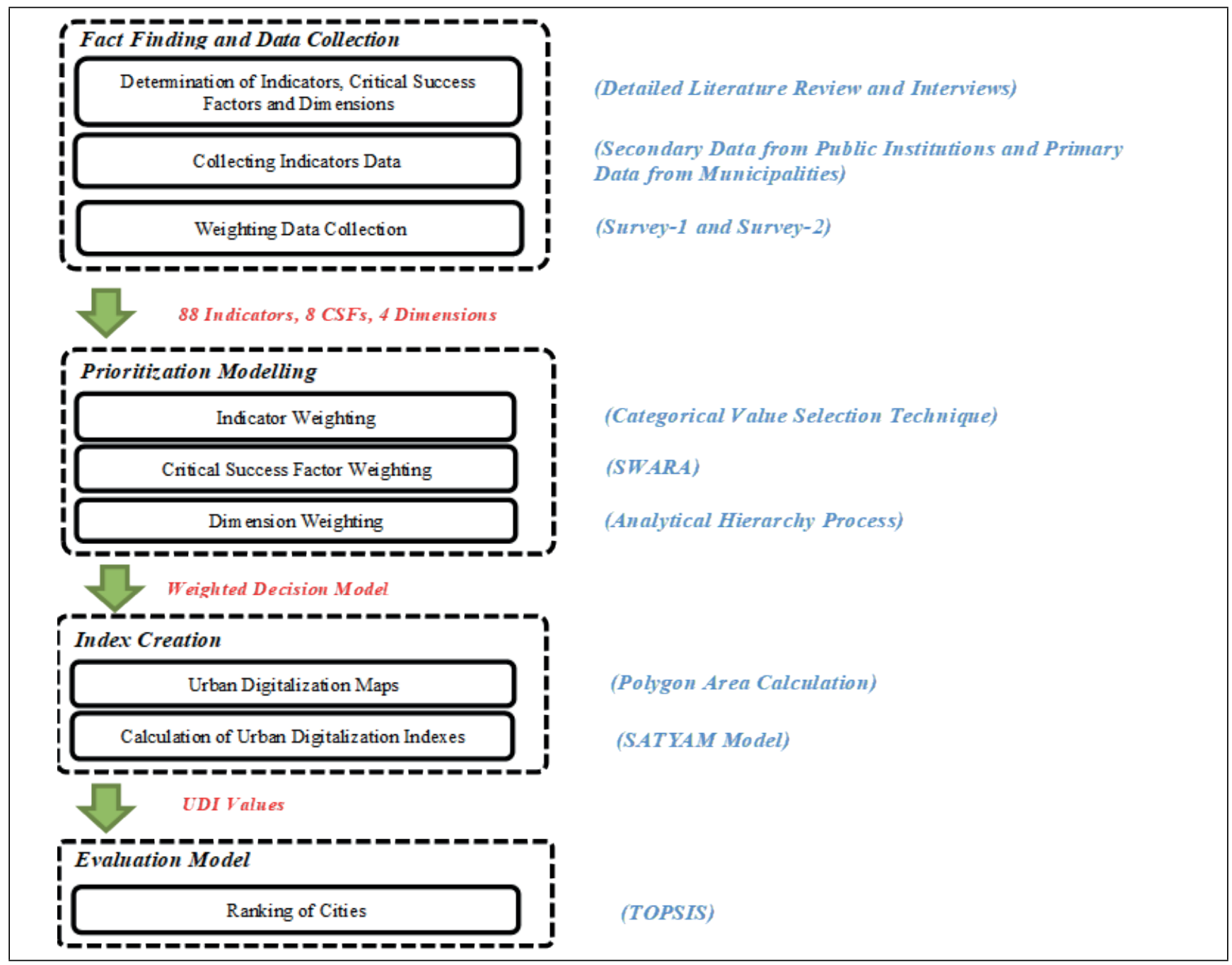

Figure 1. Data Processing Model of the Research

As a research strategy, firstly, with the help of literature review, different MCDM techniques were investigated to find the weights of indicators, dimensions, and CSFs affecting the Digital Transformation of Cities in the research. At the end of the investigation, it was decided that it would be appropriate to use SWARA to calculate CSF weights, AHP for calculating dimension weights, and Categorical Value Selection techniques for calculating indicator weights. Using these techniques, the data required to find the weights via Survey-1 and Survey-2, which are prepared on the internet, was decided. The surveys were answered by experts in the IS department of the city municipalities. Two emails were sent to the IS departments of 81 provincial municipalities to answer the s urveys, 15 days apart. In the Zonguldak districts, it was ensured that the Survey-1 on the internet was filled during the interviews. The TSO experts answered the Survey-1 questions besides Municipality IS experts in Zonguldak.

Thirty-nine (39) experts from 21 provinces participated in the surveys. 4 of them were female, and 35 were male. Three of the experts were high school graduates, $1 \mathrm{MYO}, 16$ undergraduate, 15 masters, and 4 doctoral graduates.

The SWARA technique was used to calculate CSF percentage weights, and the AHP technique was used in calculating dimension percentage weights with the results of the independent questions from Survey-1. Dimension percentage (\%) weights were calculated from the 10th question, and CSF percentage (\%) weights were calculated from the 11th question in Survey-1. These values were used to calculate the weighted-dimension and CRF UDIs, then the cities were ranked with these UDI values.

AHP was used to calculate dimension percent weights because it was easy to determine the degree of significance among the four dimensions and easily understood by IS experts. The same technique could not be used to calculate CSF percent 
weights because the 9 CSFs require too many evaluations (36 options) among themselves. In the experiments conducted during the interviews, it was observed that the AHP questions consisting of 36 options for CRFs were not answered correctly by the IS and TSO experts. For example, an expert who stated that CSF6 is more valuable than CSF7 and that CSF7 is more valuable than CSF1, later pointed out that CSF1 is more valuable than CSF6. It was seen that they could not understand the reasons for this evaluation because of the complexities. Therefore, ranking questions were prepared to determine the CSF percentages, and the answers to these ranking questions were evaluated with the help of the more appropriate SWARA technique. The ordering of $9 \mathrm{CSF}$ s from the least important to the most important (from 1 to 9 ) was easily understood and answered by experts. In the findings section of the research, how the SWARA and AHP techniques are used is explained in detail.

Indicator weights were found using the "Categorical Value Selection" technique with the help of 5 -categorical $(0,1,2,3,4)$ answers given to 6-14th questions in the Survey-2. In this technique, a 5-categorical evaluation was used for indicator percentage weights because it seemed challenging to evaluate 88 indicators by IS experts any other way. Application Details of the technique are explained in the findings section.

In addition to the communication and demographic data of those who responded to Survey-1, duty, and institution data were also collected. In Survey-1, AHP questions for dimensions and ranking questions in CSFs were asked. By October 31, 2020, 23 experts answered Survey-1. The answers from the survey were used in the calculation of CSF and dimension percentage weights. With Survey-2 prepared in Google forms, municipal IS experts were asked to evaluate 88 indicators (Annex-1) by choosing a value from the 5-categorical value. By October 31, 2020, 16 experts answered Survey-2. As mentioned before, the related weighted Ratios were calculated by multiplying the weight percentages with the Digitization Ratio (a/b). The weighted indicator, dimension, and CSF UDIs were found, and cities were ranked with the help of these UDIs. Then to make them more useful, these three different weighted rankings were transformed into an integrated-weighted UDI ranking with the TOPSIS technique.

As can be seen from the above explanations, in this study, a hybrid approach (positivist + interpretive ) was used in terms of research approach (methodology). MCDM techniques such as Categorical Value Selection, SWARA, and AHP were used to calculate indicator, dimension, and CSF weight values with a positivist approach. An interpretative approach was chosen by referring to the opinions of IS experts in determining the weight percentages.

\section{FINDINGS}

Indicators, dimensions, and CSFs are taken as basic parameters that affect the smartness or the level of Digital Transformation of cities. They contribute to the competitiveness of cities in the UDI ranking. However, since the contribution of each indicator, dimension, and CSF may be different in this competition, their weights should be determined. For this purpose, MCDM techniques described in the literature review were used. As a result of applying these MCDM techniques used in the research, the following findings were obtained.

Application of SWARA Technique: Each CSF in Survey-1 was ranked by the experts from 1 to 9, from the least valuable to the most valuable. It has been explained to the experts that each CSF should take a single value between 1 and 9. Seven (7) experts answered the survey filled out during the interviews held in Zonguldak districts. Survey-1, which was filled out on the internet by the provincial Municipality IS experts, was answered by 16 experts. However, four expert answers were not evaluated because they did not make the desired order (unique) correctly. Collected survey responses were processed on an Excel spreadsheet.

On the other hand, Table-2 shows how the first expert (E-1) answered Survey-1, and his answers were evaluated in the SWARA technique. The $\mathrm{Sj}$ value in the table shows how much each CSF is valued in percent (\%) compared to the next CSF in the ranking by the expert. For example, the E-1 stated that CSF6 (Smart City Applications) is 10\% more valuable than CSF1 (Technology Infrastructure), and CSF1 is also 10\% more valuable than CSF2. 
Table 2

Expert-1 SWARA Calculation Results in Weighting CSFS

\begin{tabular}{|c|c|c|c|c|c|c|c|c|}
\hline \multirow{2}{*}{$\begin{array}{l}\text { Criteria } \\
\text { CSF1 (Technology Infrastructure) }\end{array}$} & \multirow{2}{*}{$\begin{array}{l}\text { Selected Rank in } \\
\text { the Survey (Least } \\
\text { to Most Valuable) } \\
8\end{array}$} & \multicolumn{2}{|c|}{$\begin{array}{c}\text { Ranking (Most } \\
\text { Valuable to Least } \\
\text { Valuable) }\end{array}$} & \multirow[t]{2}{*}{ Sj } & \multirow{2}{*}{$\begin{array}{r}\mathbf{K j} \\
1.00\end{array}$} & \multirow{2}{*}{$\begin{array}{c}\text { Qj } \\
1.000\end{array}$} & \multirow{2}{*}{$\begin{array}{c}\mathbf{W j} \\
0.156\end{array}$} & \multirow{2}{*}{$\begin{array}{c}\text { \% Ratio } \\
15.6 \%\end{array}$} \\
\hline & & CSF6 & 1 & & & & & \\
\hline CSF2 (Technology Adoption) & 7 & CSF1 & 2 & 0.10 & 1.10 & 0.909 & 0.142 & $14.2 \%$ \\
\hline CSF3 (Human Capital) & 6 & CSF2 & 3 & 0.10 & 1.10 & 0.826 & 0.129 & $12.9 \%$ \\
\hline CSF4 (Meeting Human Needs) & 3 & CSF3 & 4 & 0.05 & 1.05 & 0.787 & 0.123 & $12.3 \%$ \\
\hline CSF5 (Municipal Governance) & 4 & CSF9 & 5 & 0.10 & 1.10 & 0.716 & 0.112 & $11.2 \%$ \\
\hline CSF6 (Smart City Applications) & 9 & CSF5 & 6 & 0.10 & 1.10 & 0.650 & 0.102 & $10.2 \%$ \\
\hline CSF7 (Ease of Doing Business) & 1 & CSF4 & 7 & 0.15 & 1.15 & 0.566 & 0.088 & $8.8 \%$ \\
\hline CSF8 (Innovation Environment) & 2 & CSF8 & 8 & 0.15 & 1.15 & 0.492 & 0.077 & $7.7 \%$ \\
\hline \multirow[t]{2}{*}{ CSF9 (Digital Market) } & 5 & CSF7 & 9 & 0.10 & 1.10 & 0.447 & 0.070 & $7.0 \%$ \\
\hline & & & & \multicolumn{2}{|c|}{ Total } & 6.393 & 1.00 & $100 \%$ \\
\hline
\end{tabular}

Again, as can be seen from Table-2, $\mathrm{Kj}$ values were found by adding +1 to the $\mathrm{Sj}$ values. Qj values are determined according to the place of CSF in the ranking. If the relevant CSF is in the 1st rank, $\mathrm{Qj}=1$ (as seen in Formula 3 ) is taken. In other cases, it is calculated by the Formula $\mathrm{Qj}=\mathrm{Q}(\mathrm{j}-1)$ / Kj (as seen in Formula 4). For example, in Table-2, Q1 = 1,000 for CSF6 and Q2 $=\mathrm{Q} 1 / \mathrm{K} 2=1.00 / 1.10=0.909$ for CSF1. On the other hand, Wj weight values were calculated with the help of Formula no five by normalization. Each Qj value is normalized by dividing the total value of Qj. For example, W1 = $1 / 6.393=0.156$ and $\mathrm{W} 2=0.909 / 6.393=0.142$. As a result, after the 19 IS expert answers were calculated one by one, as seen in Table-2, they were combined in Table-3. The Geometric Mean and percent (\%) Ratios of 19 expert responses are shown in Table-3.

Table 3

SWARA Calculation Totals in Finding Each CSF \% Ratio

\begin{tabular}{lcc} 
Criteria & Geometric Mean (Wj) & \% Ratio \\
\hline CSF1 (Technology Infrastructure) & 0.130 \\
CSF2 (Technology Adoption) & 0.107 & $13.37 \%$ \\
CSF3 (Human Capital) & 0.114 & 0.116 \\
CSF4 (Meeting Human Needs) & 0.120 \\
CSF5 (Municipal Governance) & 0.109 \\
CSF6 (Smart City Applications) & 0.093 \\
CSF7 (Ease of Doing Business) & 0.100 \\
CSF8 (Innovation Environment) & 0.085 \\
CSF9 (Digital Market) & $11.96 \%$ \\
Total: & $11.19 \%$ & $9.52 \%$ \\
\end{tabular}

As can be seen from the Geometric Average Column of Table-3, the geometric mean of each CSF was calculated by taking the geometric mean of the $\mathrm{Wj}$ values calculated for each CSF of all experts. To find the \% Ratio values in Table-3, the Geometric Mean value in each row was divided by the total Geometric Mean of 0.974 . For example, CSF $1 \%=0.130 / 0.974$ $=13.37$. These ratios were used to calculate the CSF-weighted UDIs used in the weighting of the CSFs and the ranking of the cities. For example, the \% Ratios in Table-3 were multiplied by the Digitization Ratio $(\mathrm{a} / \mathrm{b})$ in Table-9 and used to calculate the CSF Ratios. Then, the CSF weighted UDIs used in the ranking of the cities in Table-9.

Application of AHP Technique: 16 experts answered the 11th question of Survey-1 conducted in 81 provincial municipalities. Since the 11th question was included in Survey-1 after the interview surveys conducted in the Zonguldak districts, seven people had no answers to determine the dimension weights.

The upper part of Table-4 shows the Geometric Mean values of the transformed answers of 16 experts. The deals in the lower part of Table- 4 were found by dividing one by the values in the upper part. Other AHP calculation values and results made with Excel are listed in Table-4 without going into detail. Here, calculations were made by taking the Geometric Mean values of the answers given to the survey. Saaty recommends this Geometric Mean calculation as stated in (Timor, 2011). 
Table 4

Finding Weight Percentages (\%) of Dimensions with AHP Technique

\begin{tabular}{|c|c|c|c|c|c|c|}
\hline & & \multicolumn{2}{|c|}{ Smart Technology } & Smart People & Smart Governance & Smart Economy \\
\hline No & $\begin{array}{l}\text { Digitization Dimen- } \\
\text { sions }\end{array}$ & \multicolumn{2}{|c|}{ B1 } & B2 & B3 & B4 \\
\hline 1 & Smart Technology & \multicolumn{2}{|c|}{ B1 1.000} & 0.419 & 0.399 & 1.093 \\
\hline 2 & Smart People & \multicolumn{2}{|c|}{ B2 2.388} & 1.000 & 0.785 & 1.725 \\
\hline 3 & Smart Governance & \multicolumn{2}{|c|}{ B3 2.507} & 1.274 & 1.000 & 1.208 \\
\hline 4 & Smart Economy & \multicolumn{2}{|c|}{ B4 0.915} & 0.580 & 0.828 & 1.000 \\
\hline \multicolumn{2}{|c|}{ Total (a): } & \multicolumn{2}{|c|}{6.810} & 3.273 & 6.810 & 3.273 \\
\hline \multirow{5}{*}{\multicolumn{2}{|c|}{ Data Divided by Total /a) }} & B1 & B2 & B3 & B4 & Ratio \% (b) \\
\hline & & B1 0.147 & 0.128 & 0.132 & 0.218 & $15.62 \%$ \\
\hline & & B2 0.351 & 0.306 & 0.261 & 0.343 & $31.50 \%$ \\
\hline & & B3 0.368 & 0.389 & 0.332 & 0.240 & $33.25 \%$ \\
\hline & & B4 0.134 & 0.177 & 0.275 & 0.199 & $19.63 \%$ \\
\hline \multicolumn{2}{|c|}{ Total: } & 1.000 & 1.000 & 1.000 & 1.000 & $100 \%$ \\
\hline
\end{tabular}

As can be seen from Table-4, percent weights are given in the Ratio \% (b) column. Here, the calculation is made by dividing each dimension value by its total value. For B1, for example, $1 / 6.810=0.147$. Then, Ratio \% (b) values were found by taking the average of each row. Thus, it was found that B1 was $15.62 \%$, B2 was 31.50\%, B3 was 33.25\%, and B4 was $19.63 \%$. Lambda, CI (Consistency Index), and CR (Consistency Ratio) values are calculated to evaluate the validity of these results. These Lambda, CI, and CR values are used to determine whether the calculation is appropriate or whether the answers given are consistent. These calculation results are shown in Table-5.

Table 5

Evaluation of Validity of Dimension \% Values Calculated with AHP Technique

\begin{tabular}{|c|c|c|c|c|c|c|c|}
\hline & \multirow[b]{3}{*}{ B1 } & & & & & & \\
\hline & & B1 & B2 & B3 & B4 & Total & Total/Avg. \\
\hline \multirow{4}{*}{$\begin{array}{l}\text { Multiplying Data by Ratio } \\
\% \text { (b) }\end{array}$} & & 0.156 & 0.132 & 0.133 & 0.215 & 0.635 & 4.068 \\
\hline & B2 & 0.373 & 0.315 & 0.261 & 0.339 & 1.288 & 4.088 \\
\hline & B3 & 0.392 & 0.401 & 0.332 & 0.237 & 1.363 & 4.098 \\
\hline & B4 & 0.143 & 0.183 & 0.275 & 0.196 & 0.797 & 4.060 \\
\hline \multirow{2}{*}{$\begin{array}{l}\text { Calculation of Parameters } \\
4.078\end{array}$} & & LAMDA & CI & CR & & & \\
\hline & & 0.026 & 0.029 & & & & \\
\hline
\end{tabular}

The CR value of 0.029 indicates an acceptable result since the inconsistency rate is lower than 0.10 determined in the AHP technique. The Lambda value was found to be 4,078, and the CI value was also found to be 0,026 . The Random Value Index (RI) used in the calculation here was taken as 0.90 because there are four dimensions. The values seen in Table- 4 and 5 are calculated automatically from the survey answers with the help of formulas prepared in Excel. For example, the Ratio \% in Table- 4 was used to calculate the Dimension Ratios by multiplying the Digitization Ratio (a/b) in Table- 8 and then calculating the weighted Dimension UDIs in Table-8 used in ranking cities.

Application of Categorical Value Selection Technique: In order to determine the indicator weights, the indicator selection data from Survey-2 were used. For example, Table-6 lists the 13 indicator answers and calculation numbers of CSF-1. Here, the weight ratio $\%$ of each indicator is calculated over the total weight given to 88 indicators. The calculations were made over categorical values $(0,1,2,3,4)$ and given 88 indicators. Here, the option value 0 means that the indicator has nothing to do with the city's Digital Transformation. In contrast, the four values means that the indicator has the most essential or indispensable impact on the Digital Transformation of the city. Later, these indicators were collected for each CSF, and the "Normalized Indicator Weight Ratio (\%)" values of that CSF were calculated with formula 8. 
Table 6

Calculation of Indicator Weight Values for CSFS

\begin{tabular}{|c|c|c|c|c|c|c|c|c|c|c|}
\hline No & CSF-1: Technology Infrastructure Indicators & $\mathbf{0}$ & 1 & 2 & 3 & 4 & $\begin{array}{l}\text { Surveyor } \\
\text { Number }\end{array}$ & $\begin{array}{l}\text { Indicator } \\
\text { Value }\end{array}$ & $\begin{array}{c}\text { Normalized } \\
\text { Indicator } \\
\text { Value }\end{array}$ & $\begin{array}{c}\text { Normalized } \\
\text { Indicator } \\
\text { Weight } \\
\text { Ratio (\%) }\end{array}$ \\
\hline 1 & Number of fixed telephone subscribers per 1000 people in the city & 2 & 8 & 4 & 2 & 0 & 16 & 1.38 & 0.11 & $0.23 \%$ \\
\hline 2 & $\begin{array}{l}\text { Number of fixed broadband (Fiber, xDSL, Cable, Other) internet sub- } \\
\text { scribers per } 1000 \text { inhabitants in the city }\end{array}$ & 0 & 0 & 3 & 7 & 6 & 16 & 3.19 & 0.89 & $1.87 \%$ \\
\hline 3 & $\begin{array}{l}\text { Number of mobile }(3 / 4.5 / 5 \mathrm{G}) \text { internet subscribers per } 1000 \text { people in } \\
\text { the city }\end{array}$ & 0 & 0 & 1 & 7 & 8 & 16 & 3.44 & 1.00 & $2.09 \%$ \\
\hline 4 & ADSL average download/upload speed in the city (MB/Sec.) & 0 & 3 & 5 & 5 & 3 & 16 & 2.50 & 0.59 & $1.24 \%$ \\
\hline 5 & Average monthly broadband internet price in the city (£/Month) & 0 & 1 & 3 & 5 & 7 & 16 & 3.13 & 0.86 & $1.81 \%$ \\
\hline 6 & Number of mobile phone subscribers per 1000 people in the city & 0 & 0 & 1 & 7 & 8 & 16 & 3.44 & 1.00 & $2.09 \%$ \\
\hline 7 & Mobile internet $(3 / 4 / 5 \mathrm{G})$ broadband speed $(\mathrm{MB} / \mathrm{Sec}$.$) in the city$ & 0 & 2 & 1 & 4 & 9 & 16 & 3.25 & 0.92 & $1.92 \%$ \\
\hline 8 & Average monthly mobile phone cost in the city ( $€ /$ Month) & 0 & 1 & 4 & 4 & 7 & 16 & 3.06 & 0.84 & $1.75 \%$ \\
\hline 9 & Number of free public Wi-Fi Hotspots per $10 \mathrm{Km} 2$ in the city & 1 & 2 & 3 & 3 & 7 & 16 & 2.81 & 0.73 & $1.53 \%$ \\
\hline 10 & $\begin{array}{l}\text { Is there a Wireless Municipal Internet Network (WMIN) in the city? } \\
(\mathrm{Y}=1 / \mathrm{N}=0)\end{array}$ & 1 & 5 & 0 & 4 & 6 & 16 & 2.56 & 0.62 & $1.30 \%$ \\
\hline 11 & $\begin{array}{l}\text { Is there a Wi-Fi } 6.0 \text { Infrastructure for the Internet of Things sensor } \\
\text { (water, electricity, gas meter) in the city? }(\mathrm{Y}=1 / \mathrm{N}=0)\end{array}$ & 1 & 6 & 2 & 3 & 4 & 16 & 2.19 & 0.46 & $0.96 \%$ \\
\hline 12 & Number of Cable TV subscribers per 1000 people in the city & 6 & 5 & 2 & 3 & 0 & 16 & 1.13 & 0.00 & $0.00 \%$ \\
\hline 13 & Number of CCTV security cameras per $10 \mathrm{~km} 2$ in the city & 2 & 1 & 5 & 4 & 4 & 16 & 2.44 & 0.57 & $1.19 \%$ \\
\hline \multicolumn{2}{|c|}{ CSF1 Total } & & & & & & & 34.50 & 8.59 & $17.98 \%$ \\
\hline
\end{tabular}

The calculations in Table- 6 were made with the help of formulas 6, 7, and 8, which are given in the literature review section. The calculations in Table- 6 were repeated in the other 8 CSFs, and as a result, the CSF weight $\%$ total values of the indicators listed in Table-7 were found. The Normalized Indicator Weight Ratios (\%) were used in weighting indicators and calculating the weighted indicator UDIs used in ranking cities. For example, the Normalized Indicator Weight Ratio (\%) in Table-7 was used to calculate the Indicator Ratios by multiplying the Digitization Ratio (a/b) in Table- 8 and then calculating the weighted Indicator UDIs in Table-8, which are used in ranking cities.

Table 7

Calculation of CSF Weight Percentages of Indicators

Indicator Value

Normalized Indicator

Value

Normalized Indicator

Weight Ratio (\%)

\begin{tabular}{ccccccccccc}
\hline CSF-1 & CSF-2 & CSF-3 & CSF-4 & CSF-5 & CSF-6 & CSF-7 & CSF-8 & CSF-9 & Total \\
\hline 34.50 & 23.44 & 23.63 & 21.75 & 30.25 & 24.31 & 15.69 & 19.38 & 16.63 & 209.56 \\
8.59 & 5.76 & 5.35 & 4.54 & 7.73 & 5.16 & 2.89 & 4.00 & 3.78 & 47.81 \\
$17.98 \%$ & $12.04 \%$ & $11.19 \%$ & $9.50 \%$ & $16.17 \%$ & $10.80 \%$ & $6.05 \%$ & $8.37 \%$ & $7.91 \%$ & $100 \%$ \\
\hline
\end{tabular}

After finding the indicator, CSF, and dimension percentage weights described above, Urban Digitization Index values of 81 provinces were calculated by the Satyam UDI calculation technique. At the end of the operations described and summarized in the methods section, Digitization Ratio (a/b), UDI, CSF Weighted UDI, Indicator Weighted UDI, and Dimension Weighted UDI values were calculated. However, the ranking in Table-8, where only the top 10 provinces results are shown, was made according to the UDI column. In the last column of the table, whether the relevant provincial municipality has a Smart City project or not is given as information.. As can be seen in the bottom line of the table, it has been reported by the municipalities that 43 of the 81 provinces have SC projects. However, it can be said that only 12 municipalities have budgeted and implemented $\mathrm{SC}$ projects from the phone calls and examinations on their Web sites. 
Table 8

Urban Digitalization Index Values and Ranking of Provinces (top 10 provinces)

\begin{tabular}{|c|c|c|c|c|c|c|c|c|c|}
\hline No & Province Name & Measured (a) & Required (b) & $\begin{array}{l}\text { Digits. Ra- } \\
\text { tio }(\mathbf{a} / \mathbf{b})\end{array}$ & UDI & $\begin{array}{c}\text { Indicator } \\
\text { Weighted } \\
\text { UDI }\end{array}$ & $\begin{array}{l}\text { CSF Weight- } \\
\text { ed UDI }\end{array}$ & $\begin{array}{c}\text { Dimension } \\
\text { Weighted UDI }\end{array}$ & $\begin{array}{c}\text { Is there an } \\
\text { SC Project? }\end{array}$ \\
\hline 1 & İstanbul & 72.77 & 88 & 0.827 & 0.363 & 0.229 & 0.324 & 0.177 & 1 \\
\hline 2 & Kocaeli & 72.25 & 88 & 0.821 & 0.346 & 0.219 & 0.313 & 0.167 & 1 \\
\hline 3 & Konya & 70.76 & 88 & 0.804 & 0.330 & 0.228 & 0.312 & 0.194 & 1 \\
\hline 4 & Ankara & 68.79 & 88 & 0.782 & 0.323 & 0.197 & 0.288 & 0.151 & 1 \\
\hline 5 & İzmir & 65.78 & 88 & 0.747 & 0.287 & 0.195 & 0.266 & 0.156 & 1 \\
\hline 6 & Erzurum & 63.59 & 88 & 0.723 & 0.282 & 0.200 & 0.272 & 0.159 & 1 \\
\hline 7 & Isparta & 59.40 & 88 & 0.675 & 0.265 & 0.183 & 0.256 & 0.135 & 1 \\
\hline 8 & Denizli & 62.85 & 88 & 0.714 & 0.264 & 0.182 & 0.245 & 0.144 & 1 \\
\hline 9 & Sakarya & 60.03 & 88 & 0.682 & 0.247 & 0.160 & 0.226 & 0.124 & 1 \\
\hline \multirow[t]{2}{*}{10} & Eskişehir & 60.32 & 88 & 0.685 & 0.240 & 0.158 & 0.218 & 0.125 & 1 \\
\hline & & & & & & & & Total: & 43 \\
\hline
\end{tabular}

As it can be seen from Table-9, the rankings of provinces according to UDI (Unweighted) and different weighted UDIs values in Table-9 have been formed differently.

Table 9

Ranking of Provinces According to Different UDI Values (top 10 provinces)

\begin{tabular}{|c|c|c|c|c|c|}
\hline Province Name & $\begin{array}{l}\text { UDI (Unweighted) } \\
\text { Rank }\end{array}$ & $\begin{array}{l}\text { TOPSIS Integrated (Weight- } \\
\text { ed) UDI Rank }\end{array}$ & $\begin{array}{l}\text { Indicator Weight- } \\
\text { ed UDI Rank }\end{array}$ & $\begin{array}{c}\text { CSF Weighted UDI } \\
\text { Rank }\end{array}$ & $\begin{array}{c}\text { Dimension } \\
\text { Weighted UDI } \\
\text { Rank }\end{array}$ \\
\hline İstanbul & 1 & 1 & 1 & 1 & 2 \\
\hline Kocaeli & 2 & 3 & 3 & 2 & 3 \\
\hline Konya & 3 & 2 & 2 & 3 & 1 \\
\hline Ankara & 4 & 5 & 5 & 4 & 6 \\
\hline İzmir & 5 & 6 & 6 & 6 & 5 \\
\hline Erzurum & 6 & 4 & 4 & 5 & 4 \\
\hline Isparta & 7 & 7 & 7 & 7 & 8 \\
\hline Denizli & 8 & 8 & 8 & 8 & 7 \\
\hline Sakarya & 9 & 10 & 9 & 9 & 12 \\
\hline Eskişehir & 10 & 11 & 13 & 11 & 10 \\
\hline
\end{tabular}

When looking at the rankings made according to different UDI values in Table-9, it can be said that the formation of different rankings, after weighting the indicators, CSFs, or dimensions with the help of experts, according to different UDI values, mean a value for city municipal administrators or has statistical significance for them.

However, comparing the three different weighted (Indicator, CSF, and Dimension) UDI rankings with the unweighted UDI rank may be confusing in the decision-making process of city administrators. So, it might be beneficial in converting them into an integrated weighted ranking. For this purpose, the TOPSIS MCDM technique was used to bring three weighted UDI rankings into an integrated weighted ranking. Table-10 shows the calculation results made with the TOPSIS technique. First, the $\mathrm{Ci}$ value determining the order (as seen in Formula 12) in Table-10 is calculated by the Formula of Negative Ideal Si Value / (Negative Ideal Si Value + Positive Ideal Si Value). The relevant Si values (as seen in Formula 10 and 11) are calculated by taking the square root of the normalized sums of the three weighted ranking values. 
Table 10

Calculations of Weighted UDI Values of Provinces to Bring an Integrated Ranking with TOPSIS Method (top 10 provinces)

\begin{tabular}{|c|c|c|c|c|c|}
\hline Province Code & Province Name & Positive Ideal Si Value & Negative Ideal Si Value & $\mathbf{C i}$ & Ranking \\
\hline 34 & İstanbul & 0.002354 & 0.375491 & 0.993770 & 1 \\
\hline 41 & Kocaeli & 0.007444 & 0.369608 & 0.980256 & 3 \\
\hline 42 & Konya & 0.007062 & 0.370798 & 0.981309 & 2 \\
\hline 6 & Ankara & 0.018082 & 0.359028 & 0.952050 & 5 \\
\hline 35 & İzmir & 0.021318 & 0.355483 & 0.943425 & 6 \\
\hline 25 & Erzurum & 0.018082 & 0.359028 & 0.952050 & 4 \\
\hline 32 & Isparta & 0.029497 & 0.347242 & 0.921704 & 7 \\
\hline 20 & Denizli & 0.031846 & 0.344888 & 0.915468 & 8 \\
\hline 54 & Sakarya & 0.041649 & 0.335521 & 0.889575 & 10 \\
\hline 25 & Eskişehir & 0.047435 & 0.329630 & 0.874200 & 11 \\
\hline
\end{tabular}

The Ranking in Table-10 is shown as "TOPSIS Integrated UDI Rank" in Table-9. This TOPSIS ranking can be used as the weighted UDI ranking of cities. In this way, city managers can evaluate their cities by looking at a single integrated ranking instead of different weighted rankings and comparing them with the unweighted UDI ranking in the decisions to be taken.

As can be seen from the research findings listed above, the integration of Multi-Criteria Decision-Making techniques such as SWARA, AHP, and Categorical Value Selection with the TOPSIS technique, the calculation of the weighted Urban Digitalization Index, and the use of Satyam UDI calculation technique in this study for the first time can be seen as the factors that increase the importance of this research. However, it should not be forgotten that the obtained results are obtained under some limitations, as in every study.

\section{LIMITATIONS AND RESULTS}

As stated earlier, the aim of this research was to find the indicator, dimension, and CSF weight percentages that enable the measurement of weighted and unweighted DT Levels of cities. With the help of these, the ranking of cities was provided by extracting weighted and unweighted UDI. The three weighted UDI ranks have also been transformed into an integrated rank for easy use. The scarcity of academic research and published articles on Digital Transformation rankings of cities has been one of the main limitations because no study was found in this area.

On the other hand, the most critical limitation in this study was the dependence on the IS department experts in the cities. Many IS managers or experts could not answer the questions and surveys or were hesitant to answer because they were afraid of the municipal administrations, could not access sufficient information, or did not have time. It was observed that especially the IS departments did not look at the emails they received and did not answer the phone calls. This situation can be determined as a significant problem, especially for city citizens who implement SC projects.

Another limitation was that the dimension, CSF, and indicator weights were determined mainly by municipal IS experts because the indicator data from the field could be collected through IS experts. This group was used because they could be reached during the surveys. A limited number of responses were received to the request to fill out a questionnaire sent to 81 provincial municipalities. So, the limited number of responses given to the surveys can also be seen as a significant limitation in conducting scientific studies through municipal IS experts. In this respect, it can be said that it would be more useful to conduct such research through official channels. For example, in the interviews with the IS managers, each city IS manager answered the 497 questions sent by the Ministry of Environment and Urbanization for the "Smart City Maturity Assessment Model" (Ak1llisehirler.gov.tr, 2020) research in detail. In determining the weights, it should not be forgotten that experts from TSO, district governorship, police department, national education directorate, and private enterprises participate in these surveys, and IS experts will contribute to more balanced and inclusive survey results.

When looking at the UDI rankings results made according to weighted and unweighted values in the research, it can be said that the formation of different rankings means that the weight of indicators, dimensions, and CSFs with the help of experts is valuable for city municipal administrators or it is statistically significant for them. These weighted and unweighted UDI rankings can assist city managers in determining SC policies and developing SC strategies. 
On the other hand, it can be seen as another important result in the research that should be examined that a province (Manisa) ranks 13th in the unweighted UDI ranking and 23rd in the Weighted UDI ranking. Identifying these ranking differences can help city administrators determine where cities should pay attention to Digital Transformation strategies and management.

Again, in the study, it was observed that Konya, Kocaeli, Erzurum, and Denizli municipalities stand out in the CSF and dimension-weighted UDI rankings. The common feature of these municipalities is good at Smart City applications. It may be beneficial for metropolitan municipalities other than Istanbul, Ankara, and Izmir to benefit from the experience and practices of these municipalities.

It can be said that it can be more beneficial for city administrations and scientific research to use MCDM techniques to calculate the indicator, dimension, and CSF weighed UDIs, enabling more realistic evaluations. In addition, bringing the weighted UDI rankings to an integrated weighted ranking may be beneficial for Smart City administrators to make healthier decisions.

The use of Multi-Criteria Decision-Making techniques such as SWARA, AHP, TOPSIS, and Categorical Value Selection in the calculation of the Urban Digital Transformation Level or Smart City Indexes and the use of the Satyam UDI calculation technique in research for the first time can contribute to the enrichment of the academic literature.

As a result, it can be said that Digital Transformation is not only a technological and temporary change, but an intergenerational transformation, and it is beneficial to do all kinds of research in these areas in an age when humanity has evolved into a very different social, political and technological world. This research which ranked cities according to weighted and unweighted UDIs is one of them. This type of research is also useful in understanding today's cities.

Hakem Değerlendirmesi: Dış bağımsız.

Çıkar Çatışması: Yazarlar çıkar çatışması bildirmemiştir.

Yazar Katkıları: Çalışma Konsepti/Tasarım-M.Ç., H.İ.C.; Veri Toplama- M.Ç.; Veri Analizi/Yorumlama- M.Ç., H.İ.C.; Yazı Taslağı- M.Ç.; İçeriğin Eleştirel İncelemesi- M.Ç., H.İ.C.; Son Onay ve Sorumluluk- M.Ç., H.İ.C.

Finansal Destek: Yazarlar bu çalışma için finansal destek almadığını beyan etmiştir.

Peer-review: Externally peer-reviewed.

Conflict of Interest: The authors have no conflict of interest to declare.

Author Contributions: Conception/Design of Study- M.Ç., H.İ.C.; Data Acquisition- M.Ç.; Data Analysis/Interpretation- M.Ç., H.İ.C.; Drafting Manuscript- M.Ç.; Critical Revision of Manuscript- M.Ç., H.İ.C.;Final Approval and Accountability- M.Ç., H.İ.C.

Grant Support: The authors declared that this study has received no financial support.

\section{References/Kaynaklar}

Ahvenniemi, H., Huovila, A., Pinto-Seppä, I., \& Airaksinen, M. (2017). What are the differences between sustainable and Smart Cİties? Cities, 60, s. 234-245.

Aihemaiti, A. (2018). Türkiye'deki akıllı şehirlerin sıralama modeli. İstanbul Ticaret Üniversitesi, Fen Bilimleri Enstitüsü, Master Tezi.

Ak1llısehirler.gov.tr. (2020). Olgunluk değerlendirme modeli. https://www.akillisehirler.gov.tr/olgunluk-degerlendirme-modeli/ (21.11.2020).

Ayçin, E. (2019). Çok kriterli karar verme (1 b.). Ankara: Nobel Akademik Yayıncılık.

Baltalar, H. (2008). Analitik Hiyerarşi Süreci (AHP). http://www.hasanbaltalar.com/index.php?id=43 (10.9.2019).

Berger, R. (2019). The Smart City breakaway. How a small group of leading Digital Cities is outpacing the rest. https://www.rolandberger.com/publications/ publication_pdf/roland_berger_smart_city_breakaway_1.pdf (20.8.2019).

CBSMüdürlüğ̈̈. (2019). Akıllı Şehirler beyaz bülteni. https://webdosya.csb.gov.tr/db/cbs/akillisehirler/ (24.12.2019).

Cisco. (2018). Cisco Australian digital readiness index 2018 Digital Dividend or Digital Divide? https://www.cisco.com/c/dam/m/en_au/digital-readiness/ pdfs/digital-readiness-report.pdf (20.8.2019).

Cohen, B. (2012). What exactly is a Smart City. https://www.fastcodesign.com/1680538/what-exactly-is-a-smart-city (16.5.2018).

Cohen, B. (2015). The Smartest Cities in the World 2015: Methodology. https://www.fastcompany.com/3038818/the-smartest-cities-in-the-world-2015methodology (27.8.2019).

Coruh, M. (2009). The factors involved in utilizing e-Municipality and Municipal Wireless Network (MWN) technologies for effective, efficient and productive use of city resources in municipal governments in the Information Age. Ph.D Thesis, International School of Management, Paris.

Çoruh, M. (2021). Kentlerin Dijital Dönüşümü için Kritik Başarı Faktörlerinin belirlenmesi ve Kent Dijitalleşme Endeksi ile Kent Dijitalleşme Haritasının çıkarılması. Sakarya Üniversitesi İşletme Enstitüsü YBS Bölümü, Savunulmamış Doktora Tezi.

Çoruh, M., \& Cebeci, H. .. (2020). Zonguldak ili kentlerinin Kent Dijitalleşme Endekslerine göre sıralanması ve dijitalleşme seviyelerinin Kent Dijitalleşme Haritaları ile görselleştirilmesi. 11(30), 621-647. https://dergipark.org.tr/tr/pub/idealkent/issue/54964/654872 (12.10.2020) 
EDCi. (2016). European Digital City Index methodology report. https://digitalcityindex.eu/uploads/2016\%20EDCi\%20Construction\%20Methodology\%20 FINAL.pdf (20.8.2020).

Herzberg, C. (2017). Akıllı Şehirler dijital ülkeler. (N. Özata, Çev.) İstanbul: Infoloji Smart Solution, Optimist Yayın Grubu, Kasım 2017.

IBM. (2016). How smart is your city? Helping cities measure progress. https://www.ibm.com/downloads/cas/KLEYQE6Z (30.8.2019).

IMD. (2017). Smart City Index summary of criteria. https://www.imd.org/smart-city-observatory/smart-city-index/ (22.8.2019).

Kamrysi, K., Gotzamani, K., Andronikidis, A., \& Georgiou, A. C. (2014). Capturing and prioritizing students' requirements for course design by embedding Fuzzy-AHP and Linear Programming in QFD. Eur J Oper Res: 10831094, 237(3).

Kersuliene, V., Zavadskas, E. K., \& Turskis, Z. (2010). Selection of rational disputeresolution medhodology by applying new stepwise weight assesment ratio analysis (SWARA). Journal of Business Economics and Management, 11(2), 243-258.

Özkaya, G., \& Erdin, C. (2020). Evaluation of smart and sustainable cities through a hybrid MCDM approach based on ANP and TOPSIS technique, Heliyon (6)10, https:/www.cell.com/heliyon/fulltext/S2405-8440(20)31895-8?_returnURL=https\%3A\%2F\%2Flinkinghub.elsevier. com\%2Fretrieve\%2Fpii\%2FS2405844020318958\%3Fshowall\%3Dtrue (19.6.2021).

Saaty, T. L. (1986). Axiomatik foundation of the Analytic Hierarcy Process. Management Science, 32(7), 841-855.

Satyam, A. (2017). The Smart City transformations (e-Book). New Delhi: Bloomsbury Publishing India Pvt. Ltd., January 2017.

SCRanking. (2007). Smart Cities - Ranking of European medium-sized cities. http://www.smart-cities.eu/download/smart_cities_final_report.pdf (20.8.2019).

TBD. (2013). Bilişim kentleri k1lavuzu V5. Bilişim Teknolojileri Derneği. https://www.tbd.org.tr/wp-content/uploads/2016/07/BK-KILAVUZ-SON.pdf (10.5.2020).

Timor, M. (2011). Analitik Hiyerarşi Prosesi. İstanbul: Türkmen Kitabevi.

TÜBİSAD. (2020). Türkiye'de e-Ticaret 2019 pazar büyüklüğü. İstanbul: Türkiye Bilişim Sanayicileri Derneği, Nisan 2020. http://www.tubisad.org.tr/: http://www.tubisad.org.tr/tr/images/pdf/tubisad_e-ticaret_2019_pazar_buyuklugu_raporu.pdf (12.12.2020) 
ANNEX-1: Indicators for Calculating Dimension and CSF Values

\begin{tabular}{|c|c|c|c|}
\hline CSFs & No & Indicator Value Calculation and Scope Description & Data Source \\
\hline \multirow{11}{*}{$\begin{array}{l}\text { Technology Infra- } \\
\text { structure }\end{array}$} & 1 & Number of fixed telephone subscribers per 1000 people in the city & BTK \\
\hline & 2 & $\begin{array}{c}\text { Number of fixed broadband (Fiber, xDSL, Cable, Other) internet subscribers per } 1000 \\
\text { inhabitants in the city }\end{array}$ & BTK \\
\hline & 3 & Number of mobile $(3 / 4.5 / 5 \mathrm{G})$ internet subscribers per 1000 people in the city & BTK \\
\hline & 4 & ADSL average download/upload speed in the city (MB/Sec.) & BTK \\
\hline & 5 & Average monthly broadband internet price in the city ( $\mathrm{f} /$ Month) & BTK \\
\hline & 6 & Number of mobile phone subscribers per 1000 people in the city & BTK \\
\hline & 7 & Mobile internet $(3 / 4 / 5 \mathrm{G})$ broadband speed $(\mathrm{MB} / \mathrm{Sec}$.$) in the city$ & BTK \\
\hline & 8 & Average monthly mobile phone cost in the city (€/Month) & BTK \\
\hline & 9 & Number of free public Wi-Fi Hotspots per $10 \mathrm{Km} 2$ in the city & Municipality \\
\hline & 10 & Is there a Wireless Municipal Internet Network (WMIN) in the city? $(\mathrm{Y}=1 / \mathrm{N}=0)$ & Municipality \\
\hline & 11 & $\begin{array}{l}\text { Is there a Wi-Fi } 6.0 \text { Infrastructure for the Internet of Things sensor (water, electricity, gas } \\
\text { meter) in the city? }(\mathrm{Y}=1 / \mathrm{N}=0)\end{array}$ & Municipality \\
\hline \multirow{12}{*}{$\begin{array}{l}\text { Technology Adop- } \\
\text { tion }\end{array}$} & 12 & Number of Cable TV subscribers per 1000 people in the city & BTK \\
\hline & 13 & Number of CCTV security cameras per $10 \mathrm{~km} 2$ in the city & Police Department \\
\hline & 14 & Computer usage rate of the people in the city $(\%)$ & TUIK \\
\hline & 15 & Computer usage rate of enterprises in the city $(\%)$ & TUİK \\
\hline & 16 & The rate of ownership of a website by businesses in the city (\%) & TUIK \\
\hline & 17 & Social Media usage rate in the city $(\%)$ & BTK \\
\hline & 18 & E-Government usage rate in the city $(\%)$ & BTK \\
\hline & 19 & $\begin{array}{l}\text { Can the public or businesses in the city make an appointment to the Health Service online? } \\
\qquad(\mathrm{Y}=1 / \mathrm{N}=0)\end{array}$ & SGK \\
\hline & 20 & Is there an online voting system in the city? $(\mathrm{Y}=1 / \mathrm{N}=0)$ & Governorship \\
\hline & 21 & Are there any institutions providing online education in the city? $(\mathrm{Y}=1 / \mathrm{N}=0)$ & MEB \\
\hline & 22 & Is there $4 / 5 \mathrm{G}$ service in the city? $(\mathrm{Y}=1 / \mathrm{N}=0)$ & BTK \\
\hline & 23 & Average life expectancy of people in the city (years) & TUİK \\
\hline \multirow{8}{*}{ Human Capital } & 24 & Literacy rate of the people in the city $(\%)$ & TUİK \\
\hline & 25 & People's average schooling time in the city (years) & TUIK \\
\hline & 26 & Urban unemployment rate $(\%)$ & TUIK \\
\hline & 27 & Labor force participation rate in the city $(\%)$ & TUİK \\
\hline & 28 & Income per capita in the city $(\$)$ & TUIK \\
\hline & 29 & Ratio of people working in the ICT sector in the city $(\%)$ & TSO \\
\hline & 30 & Number of populations aged $0-14$ in the city (must be in $\%$ of Turkey) & TUIK \\
\hline & 31 & Number of university students in the city (must be in \% of Turkey) & YÖK \\
\hline \multirow{11}{*}{$\begin{array}{l}\text { Meeting Human } \\
\text { Needs }\end{array}$} & 32 & Number of lecturers in the city (must be in \% of Turkey) & YÖK \\
\hline & 33 & $\begin{array}{l}\text { Does the Municipality have an online/mobile new idea sharing application for the public? } \\
\qquad(\mathrm{Y}=1 / \mathrm{N}=0)\end{array}$ & Municipality \\
\hline & 34 & Is there an online/mobile car sharing service in the city? $(\mathrm{Y}=1 / \mathrm{N}=0)$ & Municipality \\
\hline & 35 & Is there online/mobile parking service in the city? $(\mathrm{Y}=1 / \mathrm{Y}=0)$ & Municipality \\
\hline & 36 & $\begin{array}{l}\text { Is it possible to send an email to the Mayor or the Municipality on the Municipality Web- } \\
\qquad \text { site? }(\mathrm{Y}=1 / \mathrm{N}=0)\end{array}$ & Municipality \\
\hline & 37 & $\begin{array}{l}\text { Is there a camera system that monitors the streets and intersections of the city live and } \\
\text { broadcasts them on the internet? }(\mathrm{Y}=1 / \mathrm{N}=0)\end{array}$ & Municipality \\
\hline & 38 & $\begin{array}{l}\text { Amount of electricity consumption per capita used in the city (must be in } \% \text { of Turkey } \\
\text { Average) }\end{array}$ & TUİK \\
\hline & 39 & $\begin{array}{l}\text { Is there a private Course/Official (Municipal-Public Education Centre) Institution in the } \\
\text { city that teaches Computer/Programming for adults? }(E=1 / \mathrm{H}=0)\end{array}$ & MEB \\
\hline & 40 & Are there any robotic coding classes in any of the schools in the city? $(\mathrm{Y}=1 / \mathrm{N}=0)$ & MEB \\
\hline & 41 & $\begin{array}{l}\text { Are addresses and important institutions shown on the Digital City Guide (GIS) map on } \\
\text { the Municipality's website? }(\mathrm{Y}=1 / \mathrm{N}=0)\end{array}$ & Municipality \\
\hline & 42 & Is there a Science High School or STEM school in the city? $(\mathrm{Y}=1 / \mathrm{N}=0)$ & MEB \\
\hline
\end{tabular}




\begin{tabular}{|c|c|c|c|}
\hline \multirow{11}{*}{$\begin{array}{l}\text { Municipal Gover- } \\
\text { nance }\end{array}$} & 43 & $\begin{array}{c}\text { The amount of investment made by the Municipality in ICT last year (must be } 1 \% \text { of the } \\
\text { Municipality Budget) }\end{array}$ & Municipality \\
\hline & 44 & $\begin{array}{l}\text { Are there any managers who are prone to the use of Information Technology in the Munic- } \\
\text { ipality and know how to use it? }(\mathrm{Y}=1 / \mathrm{N}=0)\end{array}$ & Municipality \\
\hline & 45 & $\begin{array}{c}\text { Are Big Data and Business Intelligence software used in decision making in the Munici- } \\
\text { pality? }(\mathrm{Y}=1 / \mathrm{N}=0)\end{array}$ & Municipality \\
\hline & 46 & Does the Municipality use Cloud Computing service? $(\mathrm{Y}=1 / \mathrm{N}=0)$ & Municipality \\
\hline & 47 & $\begin{array}{l}\text { Is there any use of Artificial Intelligence (AI) applications in municipal administration? } \\
\qquad(\mathrm{Y}=1 / \mathrm{N}=0)\end{array}$ & Municipality \\
\hline & 48 & Is there a Municipal Website? $(\mathrm{Y}=1 / \mathrm{N}=0)$ & Municipality \\
\hline & 49 & Does the Municipality have e-municipality service? $(\mathrm{Y}=1 / \mathrm{N}=0)$ & Municipality \\
\hline & 50 & Does the Municipality offer mobile applications for municipal services? $(\mathrm{Y}=1 / \mathrm{N}=0)$ & Municipality \\
\hline & 51 & $\begin{array}{c}\text { Does the Municipality have ISO } 27001 \text { Certificate and ISO } 27000 \text { Information Security } \\
\text { Management System Certificate? }(\mathrm{Y}=1 / \mathrm{N}=0)\end{array}$ & Municipality \\
\hline & 52 & Does the Municipality have an Open Data Portal? $(\mathrm{Y}=1 / \mathrm{N}=0)$ & Municipality \\
\hline & 53 & Is there a budgeted Smart City project in the city? $(\mathrm{Y}=1 / \mathrm{N}=0)$ & Municipality \\
\hline \multirow{11}{*}{$\begin{array}{l}\text { Smart City Appli- } \\
\text { cations }\end{array}$} & 54 & Is there an EDS and smart intersection system in the city? $(\mathrm{Y}=1 / \mathrm{N}=0)$ & Municipality \\
\hline & 55 & Are there Smart Lighting solutions for street lights in the city? $(\mathrm{Y}=1 / \mathrm{N}=0)$ & Municipality \\
\hline & 56 & Is there a Smart Park and Garden Irrigation system in the city? $(\mathrm{Y}=1 / \mathrm{N}=0)$ & Municipality \\
\hline & 57 & $\begin{array}{l}\text { Is there a sensor (IoT) system that checks the fullness of garbage containers in the city? } \\
\qquad(\mathrm{Y}=1 / \mathrm{N}=0)\end{array}$ & Municipality \\
\hline & 58 & $\begin{array}{l}\text { Is there a smart sensor (IoT) system that automatically reads water meters in the city? } \\
\qquad(\mathrm{Y}=1 / \mathrm{N}=0)\end{array}$ & Municipality \\
\hline & 59 & $\begin{array}{l}\text { Is there a Wi-Fi/Bluetooth system that keeps track of children and pets in the city? }(\mathrm{Y}=1 / \\
\qquad \mathrm{N}=0)\end{array}$ & Municipality \\
\hline & 60 & $\begin{array}{l}\text { Is there a system to monitor the bus arrival and departure times and line data in the city via } \\
\text { the screens at the station and the web/mobile application? }(\mathrm{Y}=1 / \mathrm{N}=0)\end{array}$ & Municipality \\
\hline & 61 & $\begin{array}{l}\text { Is there a mobile system that makes public announcements by measuring noise, humidity, } \\
\text { temperature, ice and precipitation in certain parts of the city? }(\mathrm{Y}=1 / \mathrm{N}=0)\end{array}$ & Municipality \\
\hline & 62 & Does the city have a Smart Electricity network infrastructure? $(\mathrm{Y}=1 / \mathrm{N}=0)$ & Electricity company \\
\hline & 63 & $\begin{array}{l}\text { Is there a system that monitors the official vehicles of the city municipality and records } \\
\text { video in the vehicles? }(\mathrm{Y}=1 / \mathrm{N}=0)\end{array}$ & Municipality \\
\hline & 64 & $\begin{array}{l}\text { Is there an automation center in the city that manages and monitors all Smart City applica- } \\
\text { tions? }(\mathrm{Y}=1 / \mathrm{N}=0)\end{array}$ & Municipality \\
\hline \multirow{8}{*}{$\begin{array}{l}\text { Ease of Doing } \\
\text { Business }\end{array}$} & 65 & Can IT Law and Forensic Informatics laws be used in the city $(\mathrm{Y}=1 / \mathrm{N}=0)$ & Survey \\
\hline & 66 & Logistics service quality status in the city $(\mathrm{High}=3$, medium $=2$, low $=1)$ & Survey \\
\hline & 67 & The state of the IT infrastructure quality in the city $(\mathrm{High}=3$, medium $=2$, low $=1)$ & Survey \\
\hline & 68 & Electricity connection time for a workplace in the city (days) & Electricity company \\
\hline & 69 & Time to open a business in the city (days) & TSO \\
\hline & 70 & $\begin{array}{l}\text { Number of companies with foreign capital per } 1000 \text { enterprises in the city (Must be at least } \\
\text { one) }\end{array}$ & TSO \\
\hline & 71 & Is there a Venture Capital Company or use in the city? $(\mathrm{Y}=1 / \mathrm{N}=0)$ & TSO \\
\hline & 72 & Is there a Crowdfunding Site or use in the city? $(\mathrm{Y}=1 / \mathrm{N}=0)$ & TSO \\
\hline \multirow{9}{*}{$\begin{array}{l}\text { Innovation Envi- } \\
\text { ronment }\end{array}$} & 73 & Is there a Design Centre in the city? $(\mathrm{Y}=1 / \mathrm{N}=0)$ & ATGM \\
\hline & 74 & Number of R\&D centers per 1000 companies in the city (Must be at least 1 ) & ATGM \\
\hline & 75 & Are there any special structures in the city such as Technopolis or IT Valley? $(\mathrm{Y}=1 / \mathrm{N}=0)$ & ATGM \\
\hline & 76 & Number of New Businesses opened in the city last year (must be in \% of Turkey) & TOBB \\
\hline & 77 & $\begin{array}{l}\text { Number of enterprises working in the Information and Communication (ICT) sector in the } \\
\text { city (must be in \% of Turkey) }\end{array}$ & TSO \\
\hline & 78 & Number of Registered Patents per 1000 enterprises in the city (Must be at least 1) & TürkPatent \\
\hline & 79 & Number of Registered Trademarks per 1000 businesses in the city (Must be at least 1) & TürkPatent \\
\hline & 80 & Is there an officially received/applied Geographical Indication in the city? $(Y=1 / N=0)$ & TürkPatent \\
\hline & 81 & Amount of total $R \& D$ expenditure per business in the city ( () & TUIK \\
\hline
\end{tabular}




\begin{tabular}{|c|c|c|c|}
\hline \multirow{7}{*}{ Digital Market } & 82 & Is there any foreign investment directly in the ICT sector in the city? $(\mathrm{Y}=1 / \mathrm{N}=0)$ & TSO \\
\hline & 83 & High Technology Export amount per ICT enterprise in the city (\$) & TíM \\
\hline & 84 & E-Commerce amounts per capita in the city (£) & TUBİSAT \\
\hline & 85 & Mobile (m-commerce) amounts per person in the city (£) & TUBİSAT \\
\hline & 86 & $\begin{array}{l}\text { Local demand situation for online services (e-Commerce, e-Government, e-Municipality, } \\
\text { e-Teaching etc.) in the city ( } \mathrm{High}=3 \text {, medium }=2, \text { low }=1 \text { ) }\end{array}$ & Survey \\
\hline & 87 & E-Commerce usage rate of the population in the city $(\%)$ & TUBİSAT \\
\hline & 88 & Ratio of e-Commerce amount to all commercial activities in the city (\%) & TUBISAT \\
\hline
\end{tabular}

